\title{
Metody oceny funkcji poznawczych u dzieci chorych na padaczkę leczonych dietą ketogenną
}

\author{
Methods of assessing cognitive function in children with epilepsy treated \\ with the ketogenic diet
}

\author{
Aleksandra Dąbrowska (iD, Barbara Steinborn (iD \\ Klinika Neurologii Wieku Rozwojowego, Szpital Kliniczny im. Heliodora Święcickiego Uniwersytetu Medycznego im. Karola \\ Marcinkowskiego w Poznaniu \\ Katedra i Klinika Neurologii Wieku Rozwojowego, Uniwersytet Medyczny im. K. Marcinkowskiego w Poznaniu
}

DOI:10.20966/chn.2019.57.447

\section{STRESZCZENIE}

Dieta ketogenna jest alternatywną metodą leczenia padaczki, stosowaną w przypadku chorych, u których farmakoterapia nie przynosi oczekiwanych efektów. Wśród tej grupy pacjentów bardzo często stwierdza się występowanie nieprawidłowości w przebiegu funkcji poznawczych. Deficyty mogą dotyczyć pojedynczych lub bardziej złożonych procesów. W artykule zaproponowano metody oceny funkcji poznawczych, które moga być użyteczne w diagnozie neuropsychologicznej dzieci chorych na padaczkę leczonych przy wykorzystaniu diety ketogennej. Zastosowanie tych narzędzi petni istotną rolę w określaniu poziomu funkcjonowania pacjentów w odniesieniu do norm rozwojowych oraz pozwala na obserwację zmian poznawczych w trakcie terapii.

Słowa kluczowe: funkcje poznawcze, dzieci, padaczka, dieta ketogenna
ABSTRACT

The ketogenic diet is an alternative method of epilepsy treatment applied when pharmacotherapy turns out to be ineffective. Among this group of patients cognitive disorders are often diagnosed. Deficits may concern one or more complex processes. The article proposes methods of assessing cognitive function which can be useful in the neuropsychological diagnosis of children treated with the ketogenic diet. The use of these methods plays an important role in determining the level of patients' functioning in relation to developmental norms and allows observation of cognitive changes during the therapy. Key words: cognitive function, children, epilepsy, ketogenic diet

\section{WSTĘP}

Deficyty poznawcze towarzyszące pacjentom z padaczką nie są jednorodne, podobnie jak sama choroba. Nie istnieje zatem jeden ustalony schemat deficytów poznawczych, który występowałby u wszystkich pacjentów. Aktualne dane świadczą jednak o tym, że u osób, u których rozpoznano padaczkę częściej, niż w populacji ogólnej, stwierdza się występowanie nieprawidłowości w przebiegu procesów poznawczych. Mogą one przybierać formę globalną, bądź wybiórczą. Istnieje wiele czynników, które mają wpływ na ich rodzaj i liczbę, między innymi etiologia padaczki, okres rozwojowy, w którym pojawiły się pierwsze napady, typ i częstotliwość ich występowania, a także forma leczenia $[1,2]$. Deficyty poznawcze występujące u pacjentów z padaczką są ważnym problemem klinicznym. $Z$ tego względu, ocena funkcjonowania neuropsychologicznego chorych może pełnić bardzo istotną rolę w procesie diagnostycznym, a także planowaniu i monitorowaniu interwencji terapeutycznych [3].

\section{ROLA DIAGNOZY NEUROPSYCHOLOGICZNEJ}

Wśród dzieci chorych na padaczkę leczonych przy pomocy diety ketogennej nierzadko stwierdza się występowanie nieprawidłowości $\mathrm{w}$ przebiegu procesów poznawczych i rozwoju intelektualnym. Dla przykładu, w przypadku pacjentów z zespołem Dravet, spowolnienie rozwoju i deficyty poznawcze obserwuje się po pierwszym roku życia [4]. Zespół Lennox-Gastaut, poza napadami padaczkowymi, również niesie za sobą upośledzenie funkcji poznawczych, które ulegają stopniowemu pogorszeniu i współwystępują z zaburzeniami behawioralnymi, psychiatrycznymi, a także opóźnieniem ruchowym [5]. U dzieci z GLUT1 nieprawidłowości poznawcze mogą przyjmować postać od nieznacznych trudności w uczeniu się do znaczącego opóźnienia rozwoju intelektualnego, z którym często współwystępuje zaburzony rozwój mowy [6]. Wśród osób z zespołem Sturge'a i Webera, zaburzenia poznawcze diagnozuje się u ok. $83 \%$ chorych. Poziom rozwoju psychomotorycznego jest zróżnicowany i zależy od okresu, w jakim doszło do pojawienia się napadów padaczkowych, a także ich postaci. U 2/3 dzieci opóźnienie rozwoju obserwuje się przez upływem okresu niemowlęcego. Gorsze rokowania występują w przypadku wczesnego początku napadów i nieskuteczności leczenia lekami przeciwpadaczkowymi [7]. W przypadku pacjentów ze stwardnieniem guzowatym deficyty w rozwoju są skutkiem strukturalnych zmian 
w mózgu. U 29\% pacjentów diagnozuje się jednocześnie padaczkę, znamię Pringle'a oraz niepełnosprawność intelektualną, natomiast tylko u $6 \%$ żadnego z wymienionych objawów [8].

Biorąc pod uwagę zróżnicowany obraz funkcjonowania poznawczego dzieci z padaczką oporną na leczenie, wydaje się, że w przypadku tej grupy istotną rolę odgrywa badanie neuropsychologiczne. Badanie neuropsychologiczne można zdefiniować, jako metodę diagnozy neurorozwojowych, neurodegeneracyjnych, a także nabytych zaburzeń funkcjonowania mózgu, która stanowi część ogólnej diagnozy neurologicznej. W skład tego rodzaju diagnozy wchodzi ocena zdolności intelektualnych, procesów pamięci, uwagi, planowania, analizy przestrzennej, koordynacji wzrokowo-ruchowej, umiejętności grafomotorycznych, funkcji wykonawczych, a także funkcjonowania społecznego i emocjonalnego. Rezultaty tego rodzaju badania psychologicznego są bardzo istotne w ocenie, zarówno niewielkich, jak i znaczących nieprawidłowości w przebiegu funkcji poznawczych u osób chorych, w tym wśród pacjentów z rozpoznaniem padaczki. Zebrane w badaniu informacje pozwalają na określenie poziomu funkcjonowania pacjentów w odniesieniu do norm rozwojowych, a uściślając - umożliwiają wyodrębnienie procesów rozwijających się powyżej, w normie oraz poniżej normy dla wieku. Określenie poziomu funkcjonowania poznawczego ułatwia wybór metody leczenia oraz rodzaju dalszej terapii. Diagnoza neuropsychologiczna pełni także ważną rolę dla rodziców dziecka i jego nauczycieli, przyczyniając się do akceptacji określonych zachowań, a także określenia i wdrożenia adekwatnych wymagań $[9,10]$.

Pacjenci będący na diecie ketogennej odbywają na oddziałach szpitalnych w jednakowych odstępach czasu wizyty kontrolne (najczęściej co trzy miesiące). W czasie których powtarzane są, m.in. badania pediatryczne i neurologiczne. Celem tego rodzaju pobytów w szpitalu jest ocena wpływu diety na częstość występowania napadów padaczkowych, a także wykrycie ewentualnych objawów niepożądanych $[11,12]$. Mając na względzie fakt, iż istnieją badania mówiące o tym, że dieta ketogenna wpływa na poprawę procesów poznawczych i jakość życia [13-17], ważną kwestią w czasie wizyt kontrolnych wydaje się również powtarzanie konsultacji psychologicznych, mając na uwadze zasady, które po upływie jakiego czasu można dokonać ponownej oceny danej funkcji tym samym narzędziem diagnostycznym.

\section{METODY OCENY FUNKCJI POZNAWCZYCH PACJENTÓW NA DIECIE KETOGENNEJ}

Ocena procesów poznawczych uwzględnia zarówno deficyty, jak i zasoby w zakresie funkcjonowania chorych. Istnieje wiele metod diagnostycznych, które dostarczają danych ilościowych lub jakościowych. Osoby przeprowadzające badanie mogą używać prostych testów, które badają funkcje specyficzne lub narzędzi, wymagających rozbudowanych odpowiedzi, mierzacych tych samym funkcje bardziej złożone [18]. Każdorazowo, w przypadku najmłodszych pacjentów należy również pamiętać o przeprowadzeniu szczegółowego wywiadu z rodzicami, bądź opiekunami prawnymi, w celu zebrania informacji na temat rozwoju, osiągnięć szkolnych, czy historii choroby [9].

W przypadku dzieci chorych na padaczkę leczonych dietą ketogenną w Polsce nie ma jeszcze konkretnych rekomendacji, dotyczących wyboru narzędzi diagnostycznych, służących do oceny funkcji poznawczych. W tej grupie pacjentów można dokonać wyboru spośród wielu dostępnych testów stosowanych w diagnozie neuropsychologicznej, które posiadają polską standaryzację, uwzględniając indywidualne predyspozycje oraz trudności dziecka. W chorobach układu nerwowego, w tym w padaczce, stosuje się przede wszystkim różnego typu testy przesiewowe. Wydaje się jednak, że nie istnieje idealny test przesiewowy, gdyż wiele $\mathrm{z}$ nich nie uwzględnia dzieci z zaburzeniami wzroku, słuchu, czy ruchu [9]. Analizując badania zagraniczne, koncentrujące się na wpływie diety ketogennej na funkcjonowanie dzieci (również poznawcze), można wnioskować, że metody te są zróżnicowane. Dla przykładu, w badaniach de Kinderen i wsp. z 2011 roku [15], do oceny funkcji poznawczych użyto testów, które nie posiadają polskiej standaryzacji, m.in. Peabody Vocabulary Test (PPVT-III-NL), The Beery Developmental test of Visual-Motor Integration (Beery-VMI), komputerową baterię Fepsy i The Kaufman Assessment Battery for Children II (K-ABC II). Zhu i wsp. [19] oraz Wu i wsp. [14] posłużyli się skalami rozwojowymi Gesella. Natomiast Yan i wsp. [20] zastosowali kwestionariusz oceniający uwagę, czujność i pamięć, który wypełniali opiekunowie pacjentów. Poprawę w zakresie danej funkcji uznawano na podstawie dwóch niezależnych subiektywnych opinii opiekunów dziecka.

W tabeli I przedstawiono wybrane narzędzia diagnostyczne, które mogą być użyte do oceny funkcji poznawczych u dzieci chorych na padaczkę leczonych dietą ketogenną w Polsce.

\section{PROPOZYCJE NARZEDZI SEUŻACYCH DO OCENY ROZWOJU DZIECI DO 3. ROKU ŻYCIA}

Stosowanie standardowych baterii testów neuropsychologicznych u dzieci, które nie ukończyły jeszcze trzeciego roku życia jest zbędne. W przypadku tej grupy diagnoza polega głównie na ocenie rozwoju psychoruchowego, w celu podjęcia adekwatnych wczesnych interwencji, np. rehabilitacji, jesli okaże się to konieczne [9].

O prawidłowym rozwoju psychoruchowym dziecka mówimy wtedy, kiedy dochodzi do płynnej, stopniowej integracji procesów psychicznych, intelektualnych i orientacyjno-poznawczych z rozwojem motorycznym i fizycznym. Przejście do kolejnej fazy jest możliwe po osiągnięciu i utrwaleniu etapu wcześniejszego. O opóźnieniu rozwoju świadczą braki lub wolniejsze tempo realizacji kolejnych jego faz. Spowolnienie rozwoju ruchowego może być oznaką opóźnień w sferze poznawczej, emocjonalnej i społecznej. Opóźnienie obserwuje się w jednym lub kilku obszarach (kiedy deficyty stwierdza się w co najmniej dwóch z nich, mówimy wówczas o opóźnieniu globalnym). W ocenie rozwoju psychoruchowego można posłużyć się, m.in. Skalą Rozwoju Psychomotorycznego Brunet-Lézine, bądź dokonać oceny kamieni milowych [21]. 
Tab. I. Propozycje testów, które mogą być użyte do oceny funkcji poznawczych dzieci chorych na padaczkę leczonych dietą ketogenną w Polce.

Tab I. Test proposals that can be used to assess the cognitive function in children with epilepsy treated with the ketogenic diet

\begin{tabular}{|c|c|c|}
\hline $\begin{array}{l}\text { Funkcja } \\
\text { poznawcza } \\
\text { Cognitive } \\
\text { function }\end{array}$ & $\begin{array}{l}\text { Nazwa testu } \\
\text { Name of the test }\end{array}$ & $\begin{array}{l}\text { Wiek } \\
\text { badanych } \\
\text { Age of the } \\
\text { individuals }\end{array}$ \\
\hline \multirow{5}{*}{$\begin{array}{l}\text { Inteligencja } \\
\text { ogólna } \\
\text { General } \\
\text { intelligence }\end{array}$} & $\begin{array}{l}\text { Skala Rozwoju } \\
\text { Psychomotorycznego } \\
\text { Brunet-Lézine }\end{array}$ & $1-30 \mathrm{mż}$ \\
\hline & $\begin{array}{l}\text { Międzynarodowa Skala } \\
\text { Wykonaniowa Leitera }\end{array}$ & $\begin{array}{l}\text { 3-15 rż } \\
\text { 3-14 rż (dzieci } \\
\text { głuche) }\end{array}$ \\
\hline & $\begin{array}{l}\text { Skala Dojrzałości } \\
\text { Umysłowej Columbia }\end{array}$ & $\begin{array}{l}3 ; 5(16)- \\
9 ; 11(15) \text { rż }\end{array}$ \\
\hline & $\begin{array}{l}\text { Test Matryc Ravena } \\
\text { w Wersji Kolorowej (TMK) } \\
\text { Test Matryc Ravena } \\
\text { w Wersji Standard (TMS-K) } \\
\end{array}$ & $\begin{array}{l}3 ; 11-9 ; 11 \text { rż } \\
\text { od } 6 \text { rż }\end{array}$ \\
\hline & $\begin{array}{l}\text { Skala Inteligencji Wechslera } \\
\text { dla Dzieci (WISC-R) } \\
\text { Skala Inteligencji Wechslera } \\
\text { dla Dorosłych (WAIS-R) }\end{array}$ & $\begin{array}{l}6 ; 0-16 ; 11 \text { rż } \\
\text { od } 16 \text { rż }\end{array}$ \\
\hline $\begin{array}{l}\text { Uwaga } \\
\text { Attention }\end{array}$ & Test d2 Brickenkampa & $11 ; 6-19 ; 5$ rż \\
\hline \multirow{3}{*}{$\begin{array}{l}\text { Uczenie się } \\
\text { i pamięć } \\
\text { Learning and } \\
\text { memory }\end{array}$} & Test Figury Złożonej Reya & $8 ; 6-14 ; 5$ rż \\
\hline & \begin{tabular}{|l} 
Test Pamięci Wzrokowej \\
Bentona (BVRT)
\end{tabular} & $\begin{array}{l}5 ; 0-25 ; 0 \text { rż } \\
55 ; 0-75 ; 0 \text { rż }\end{array}$ \\
\hline & Test 15 słów Reya (RAVLT) & od 7 rż \\
\hline \begin{tabular}{|l|} 
Funkcje \\
wzrokowo- \\
przestrzenne \\
Visual-spatial \\
functions \\
\end{tabular} & Test Bender-Koppitz & $5 ; 0-10 ; 11$ rż \\
\hline \multirow{4}{*}{$\begin{array}{l}\text { Funkcje } \\
\text { wykonawcze } \\
\text { Executive } \\
\text { functions }\end{array}$} & $\begin{array}{l}\text { Test Sortowania Kart } \\
\text { z Wisconsin (WCST) }\end{array}$ & od ok. 6,5 rż \\
\hline & $\begin{array}{l}\text { Test Interferencji Nazw } \\
\text { i Kolorów (Stroopa) }\end{array}$ & od ok. 5 rż \\
\hline & Test Fluencji Słownej (VFT) & od ok. 7 rż \\
\hline & $\begin{array}{l}\text { Test Łączenia Punktów } \\
\text { (TMT) }\end{array}$ & od ok. 11 rż \\
\hline
\end{tabular}

Opracowanie własne

\section{Skala Rozwoju Psychomotorycznego Brunet-Lézine}

Skala Brunet-Lézine została opracowana w latach 50. XX wieku we Francji przez Odette Brunet oraz Irène Lézine. Opublikowano ją w 1979 roku po wprowadzeniu pewnych zmian. Skala służy do oceny rozwoju dzieci od 1 do 30 miesiąca życia w obszarach, takich jak: postawa, koordy- nacja wzrokowo-ruchowa, mowa oraz kontakty społeczne. Wynik uzyskany w skali określa się mianem ilorazu rozwoju psychoruchowego (IRPR) [21,22].

\section{Kamienie milowe}

Kamienie milowe odnoszą się do konkretnych umiejętności opanowanych przez dziecko w określonej kolejności oraz czasie i są wynikiem interakcji układu nerwowego dziecka ze środowiskiem zewnętrznym. Umiejętności te dotyczą następujących obszarów: motoryka mała, motoryka duża, komunikacja, funkcje poznawcze oraz funkcje społeczno-emocjonalne. Trudności z osiągnieciem poszczególnych kamieni milowych mogą się wiązać z opóźnieniem rozwoju psychomotorycznego. Celem tego rodzaju oceny jest wczesne wykrycie deficytów wpływających na prawidłowy rozwój dziecka oraz jak najszybsze podjęcie oddziaływań terapeutycznych [23].

\section{PROPOZYCJE METOD StUŻĄYCH DO OCENY FUNKCJI POZNAWCZYCH U DZIECI STARSZYCH}

Dostępność metod diagnostycznych stosowanych w diagnozie neuropsychologicznej powyżej 3. roku życia jest znacząco większa. Trudność polega na dokładnym dopasowaniu narzędzi do pojedynczych funkcji, ponieważ zwykle badają one procesy bardziej złożone. Istnieją jednak podziały na narzędzia badające określone kategorie procesów poznawczych, którymi posługuje się w badaniu neuropsychologicznym [9].

\section{INTELIGENCJA}

Inteligencja definiowana jest jako najbardziej złożona funkcja poznawcza. Istnieje wiele wyjaśnień tego terminu, jednak mają one wiele cech wspólnych. Inteligencja wiąże się, m.in. z umiejętnością rozwiązywania problemów, planowaniem, myśleniem abstrakcyjnym, rozumieniem i uczeniem się przez doświadczenie. To zdolność do postrzegania, analizy i adaptacji do zmian zachodzących w otoczeniu, a także wykorzystywania posiadanej wiedzy w rozmaitych sytuacjach [24].

Cattell w swojej koncepcji dokonał podziału na inteligencję ,płynną", która podlega zmianom związanym z dojrzewaniem oraz inteligencję ,skrystalizowaną”, która zależy od całości doświadczenia i uczenia się w ciągu życia. Według tej teorii, inteligencja skrystalizowana pozostaje taka sama lub stale się rozwija, natomiast inteligencja płynna ulega obniżeniu pod wpływem zmian zachodzących układzie nerwowym pod wpływem czasu [25].

Testy badające poziom rozwoju procesów intelektualnych najczęściej należą do metod bardziej złożonych, składających się z podtestów. Na podstawie uzyskanych wyników określa się iloraz inteligencji [9].

\section{Międzynarodowa Skala Wykonaniowa Leitera}

Międzynarodowa Skala Wykonaniowa Leitera z 1993 roku jest narzędziem służącym do oceny intelektu u dzieci w wieku od 3 do 5 lat lub u dzieci w wieku od 3 do 14 lat, które przejawiają trudności w obszarze komunikacji werbalnej (zarówno w mowie czynnej, jak i biernej). Skala składa się z 52 zadań i serie od A do M, które różnią się 
między sobą poziomem trudności. Narzędzie to należy do grupy testów niewerbalnych i polega na odwzorowaniu z klocków układu określonego we wzorze [26].

\section{Skala Dojrzałości Umystowej Columbia}

Skala Dojrzałości Umysłowej Columbia (1990) autorstwa Bessie B. Burgemeister, Lucille Hollander Blum oraz Irving Lorge jest testem niewerbalnym przeznaczonym do oceny poziomu dojrzałości umysłowej dzieci w wieku od 4. do 10 . roku życia. Na narzędzie składa się 70 tablic z rysunkami, a zadanie dziecka polega na wskazywaniu rysunków, które nie wykazują żadnych związków z pozostałymi [27].

\section{Test Matryc Ravena}

Test Matryc Ravena czerpie swoje teoretyczne podstawy $z$ teorii Spearmana, dotyczącej inteligencji ogólnej. Narzędzie służy do pomiaru tej inteligencji, rozumianej jako inteligencja płynna. Test Matryc Ravena w Wersji Kolorowej (2003) przeznaczony jest dla dzieci w wieku 4-10 lat oraz osób z niższymi zdolnościami intelektualnymi. Składa się z trzech serii, z które każda zawiera 12 zadań. Osoba badana ma za zadanie wybranie fragmentu, który należy dopasować do niepełnej kolorowej matrycy [28]. Standardową wersję testu w formie Klasycznej (TMS-K) (2000) można stosować u dzieci od 6. do 16. roku życia. Składa się ona z serii A, B, C, D i E, a każda z nich obejmuje po 12 zadań. Wynik stanowi o aktualnych możliwościach intelektualnych dziecka [29].

\section{Skala Inteligencji Wechslera}

Skala Inteligencji Wechslera dla Dzieci (WISC-R) służy do pomiaru inteligencji ogólnej dzieci w wieku 6-16 lat, rozumianej jako inteligencja skrystalizowana. Bateria składa się z 6 testów słownych (Wiadomości, Podobieństwa, Arytmetyka, Słownik, Rozumienie i Powtarzanie Cyfr) i 6 bezsłownych (Uzupełnianie Obrazków, Porządkowanie Obrazków, Wzory z Klocków, Układanki, Kodowanie i Labirynty), z czego testy: Powtarzanie Cyfr oraz Labirynty pełnią rolę testów zastępczych. Możliwość wykonania analizy profilowej umożliwia wyodrębnienie mocniejszych i słabszych stron intelektu pacjentów [30]. Skala Inteligencji Wechslera dla Dorosłych (WAIS-R) przeznaczona dla młodzieży powyżej 16. roku życia i dorosłych. W skład baterii wchodzi 6 testów słownych (Wiadomości, Powtarzanie Cyfr, Słownik, Arytmetyka, Rozumienie i Podobieństwa) oraz 5 bezsłownych (Braki w Obrazkach, Porządkowanie Obrazków, Klocki, Układanki i Symbole Cyfr). Uważa się, że w tym przypadku Skala Bezsłowna mierzy inteligencję płynną, a Słowna skrystalizowaną [31].

\section{UWAGA}

Uwaga pełni funkcję reduktora nadmiaru informacji. Do jej głównych funkcji zalicza się:

1) selektywność, rozumianą jako umiejętność wyboru jednego bodźca lub kilku, kosztem innych,

2) czujność, rozumianą jako umiejętność wyczekiwania na pojawienie się konkretnego bodźca (sygnału), przy jednoczesnym ignorowaniu pozostałych (szumu),
3) przeszukiwanie, polegające na stałym przeszukiwaniu pola percepcyjnego, aby wykryć elementy pasujące do określonego kryterium,

4) kontrolę czynności jednoczesnych [32].

\section{Test d2 Brickenkampa}

Test $\mathrm{d} 2$ autorstwa Brickenkampa jest niewerbalną metodą służącą do pomiaru różnych aspektów uwagi, dotyczących szybkości spostrzegania, liczby błędów oraz ogólnej zdolności spostrzegania, a także koncentracji. Arkusz zawiera 14 rzędów zawierających po 47 znaków „d” i „p”, z różną liczbą kresek znajdującymi nad lub pod nimi. Osoba badana ma za zadanie wykreślenie wyłącznie liter „d” z dwiema kreskami u góry, na dole lub po jednej u góry i na dole. Badanie składa się z serii próbnej i właściwej, a także posiada ograniczenia czasowe [33].

\section{UCZENIE SIĘ I PAMIĘĆ}

Pamięć to proces polegający na rejestrowaniu, przechowywaniu i odtwarzaniu doświadczeń. Według Squire'a wyróżnia się pamięć deklaratywną (jawną) i niedeklaratywną (utajoną). Psychologia poznawcza przypisuje duże znaczenie podziałowi pamięci na krótkotrwałą (STM) i długotrwałą (LTM). Procesy pamięci można również podzielić na pamięć werbalną i niewerbalną, ikoniczną, epizodyczną oraz, w zależności od rodzaju spostrzegania, słuchową, wzrokową, dotykową, węchową, czy smakową. Ponadto, na potrzeby diagnozy neuropsychologicznej, dokonuje się rozłamu pamięci deklaratywnej na prospektywną i retrospektywną. Uczenie się jest procesem, który doprowadza do występowania zmian ujawniających się w zachowaniu i okazuje się niemożliwe bez efektywnie przebiegających procesów pamięciowych. Uczenie się i pamięć nie należą do pojęć jednoznacznych, bowiem istnieją poglądy mówiące o ich równorzędności oraz takie, które uznają jedno z nich jako nadrzędne w stosunku do drugiego $[9,32]$.

\section{Test Figury Złoionej Reya}

Test Figury Złożonej Reya stworzony przez Reya w 1941 roku, a następnie poprawiony w 1994 roku przez Osterrietha, należy do grupy popularnych testów neuropsychologicznych. Dzięki tej metodzie możliwe jest dokonanie oceny wielu procesów poznawczych, w tym pojemności bezpośredniej pamięci wzrokowej. Narzędzie to jest testem typu papier-ołówek i składa się z dwóch faz: przerysowania figury ze wzoru, a następnie reprodukcji z pamięci (po 3 minutach). W ocenie wyników testu bierze się pod uwagę typ reprodukcji, liczbę uzyskanych punktów oraz czas trwania przerysowania [34].

\section{Test Pamięci Wzrokowej Bentona}

Test Pamięci Wzrokowej Bentona (BVRT) wykorzystywany jest do oceny pamięci oraz percepcji wzrokowej. Na test składają się trzy równoległe wersje C, D i E, zawierające 10 wzorów, które mogą być badane czterema metodami (A, B, C i D). Metody różnią się od siebie czasem ekspozycji wzoru i odroczenia. Wyniki mogą być interpretowane ilościowo i jakościowo [35]. 


\section{Test 15 stów Reya}

Narzędzie to stosowane jest w ocenie pamięci deklaratywnej (werbalnej). Osoba przeprowadzająca badanie czyta badanemu pięciokrotnie 15 słów z listy A. Po każdym odczytaniu (próbie uczenia się) badany proszony jest o wymienienie słów, które zapamiętał. Po zakończeniu pięciu prób prezentowana jest druga lista 15 słów (B), po której osoba badana proszona jest ponowne odtworzenie listy A dwukrotnie: bezpośrednio po dystrakcji oraz po upływie 20 minut [36].

\section{ZDOLNOŚCI WZROKOWO-PRZESTRZENNE}

Funkcje wzrokowo-przestrzenne polegają przede wszystkim na prawidłowym postrzeganiu oraz manipulowaniu informacjami odbieranymi wzrokowo oraz cechami przestrzennymi obiektów. Dotyczą także zdolności konstrukcyjnych. Procesy te oceniane są $\mathrm{w}$ testach wymagających przerysowywania określonych kształtów, złożonych figur, czy rozpoznawania niepełnych obiektów [9]. W badaniu neuropsychologicznym dzieci do oceny funkcji zdolności wzrokowo-przestrzennych stosuje się, m.in. Test Bender-Koppitz oraz Test Figury Złożonej Reya, który został już w niniejszej pracy opisany.

\section{Test Bender-Koppitz}

Test Bender-Koppitz należy do narzędzi pomocnych w ocenie rozwoju procesów wzrokowo-przestrzennych oraz wykryciu ewentualnego opóźnienia w tym aspekcie, które może przekładać się na swobodne nabywanie podstawowych umiejętności szkolnych (czytanie, pisanie, liczenie). Test składa się z 9 wzorów figur geometrycznych, które badany kolejno przerysowuje na kartkę papieru w formacie A4. W przypadku oceny osób z chorobami ośrodkowego układu nerwowego, istotną rolę odgrywa rodzaj popełnianych przez dziecko błędów. Koppitz zalicza do nich: zniekształcenia, rotacje, wadliwą integrację części figury oraz perseweracje [37].

\section{FUNKCJE WYKONAWCZE}

Koncepcja funkcji wykonawczych należy do koncepcji złożonych i nadal rozwijających się w neuropsychologii klinicznej. Obecnie termin ten rozumiany jest na dwa sposoby. Z jednej strony, mówi się o nadrzędnej roli funkcji wykonawczych nad pozostałymi procesami poznawczymi. $\mathrm{Z}$ drugiej, nie dokonuje się takiego rozróżnienia i traktuje się sferę wykonawczą jako część sfery poznawczej, znajdującej się na kontinuum między poznaniem a zachowaniem. Funkcje wykonawcze są odpowiedzialne za określenie celu działania i rezultatów zachowań, kreowanie alternatywnych planów, inicjowanie i zachowania zachowania intencjonalnego, a także zmianę zachowania, w zależności od okoliczności i trwanie przy zamiarze. Zaburzenia w obszarze tych funkcji obserwowane są w przebiegu wielu chorób układu nerwowego, w tym w padaczce. Do oceny tego obszaru stosuje się metody przesiewowe oraz psychometryczne [38, 39].

\section{Test Sortowania Kart $z$ Wisconsin}

Test Sortowania Kart z Wisconsin (WCST) stosowany wśród dzieci, młodzieży i dorosłych w ocenie funkcji po- znawczych, rozumianych jako procesy sprawujące kontrolę i sterujące aktywnością poznawczą człowieka. Autorem standardowej wersji testu jest Robert Heaton, który w 1981 roku opublikował pierwszy podręcznik do narzędzia. WCST zawiera dwie talie kart, a każda zawiera ich po 64 . Osoba badana samodzielnie określa regułę, według której dokonuje sortowania (ale otrzymuje informację zwrotną, czy udzieliła prawidłowej odpowiedzi) [40].

\section{Test Interferencji Nazw i Kolorów (Stroopa)}

Test Stroopa powstał w wyniku badań Cattella (1886) nad szybkością reakcji na różnorodne bodźce wzrokowe. Narzędzie składa się z ciągu słów, które oznaczają kolory, jednak słowa te są wydrukowane innymi kolorami niż ich znaczenie. Oryginalna metoda polega na określaniu koloru, w jakim zostało wydrukowane słowo, a nie jego czytaniu. Biorąc pod uwagę tendencję do zautomatyzowanego czytania, nazywanie barw może okazać się kłopotliwe. Mówi się wtedy o efekcie Stroopa lub efekcie interferencji. W innych wersjach testu liczony jest również czas reakcji oraz ilość błędów, a także dodawane są dodatkowe karty [38].

\section{Test Fluencji Stownej}

Test Fluencji Słownej (TFS) polega na wygenerowaniu przez osobę badaną w określonym czasie (najczęściej w ciągu jednej minuty) jak największej liczby słów, które spełniają podane kryterium. TFS umożliwia określenie płynności słownej semantycznej, nazywanej kategorialną oraz literowej, fonemicznej. W przypadku płynności kategorialnej, kategorię mogą stanowić, np. „zwierzęta”. W ocenie płynności fonemicznej osoba badana ma za zadanie wymawiać słowa rozpoczynające się na określoną głoskę, np. F. W standardowej wersji narzędzia dokonuje się oceny ilościowej, nie wliczając wyrazów błędnych i powtarzających się [41].

\section{Test Łączenia Punktów}

We współczesnej diagnozie neuropsychologicznej, Test Łączenia punktów (TMT) zorientowany jest na pomiar kontroli wykonawczej, w tym kontroli hamowania. Jej utrata skutkuje sztywnością reakcji oraz przebiegu procesów psychicznych i z tego powodu mówi się, że TMT może wykrywać symptomy uszkodzenia mózgu. Test składa się z dwóch części - A i B. W pierwszej części zadanie polega na jak najszybszym połączeniu ponumerowanych od 1 do 25 i rozmieszonych w różnych miejscach kartki kółek, natomiast druga (B) na łączeniu na przemian cyfr i liter, np. 1-A-2-B-3-C i tak dalej [38].

\section{ZAKOŃCZENIE}

W niniejszym artykule nie opisano wszystkich dostępnych metod diagnostycznych. Ze względu na brak oficjalnych rekomendacji, przedstawiono propozycje narzędzi stosowanych w diagnozie neuropsychologicznej, które mogą być również używane wśród pacjentów z padaczką leczonych dietą ketogenną. Dostępnych jest jeszcze wiele innych testów, z których część nie posiada polskiej standaryzacji. Należy również poruszyć kwestię ograniczeń poszczególnych metod. Wybór niektórych narzędzi może 
okazać się nietrafny, ze względu na specyficzne trudności pacjentów, które nie były brane pod uwagę w procesie ich konstruowania. Wcześniejsze planowanie badania (w miarę możliwości) oraz przeprowadzenie szczegółowego wywiadu z rodzicami wydają się ważnymi elementami całego procesu diagnostycznego.

\section{PIŚMIENNICTWO}

[1] Gugata-Iwaniuk M., Bochyńska A.: Funkcjonowanie poznawczobehawioralne osób z padaczką. Przegląd literatury. Postępy Psychiatrii i Neurologii 2014; 23: 140-146.

[2] Mojs E.: Neurorehabilitacja w padaczce wieku rozwojowego. [w:] Psychologia w naukach medycznych. Cybulski M., Strzelecki W. [red.], Uniwersytet Medyczny im. Karola Marcinkowskiego w Poznaniu, Poznań 2010.

[3] Helmstaedter Ch., Witt J.A.: Clinical neuropsychology in epilepsy: theoretical and practical issues. Handbook of Clinical Neurology 2012; 107: 437-459.

[4] Shmuely S., Sisodiya S.M, Gunning W.B., et al.: Mortality in Dravet syndrome: A review. Epilepsy \& Behaviour 2016; 64: 69-74.

[5] Balagura G., Riva A., Marchese F., et al.: Adjunctive Rufinamide in Children with Lennox-Gestaut Syndrome: A Literature Review. Neuropsychiatric Disease and Treatment 2020; 16: 369-379.

[6] Wang D., Pascual J.M., De Vivo D.: Glucose Transporter Type 1 Deficiency Syndrome. GeneReviews 2018, Address: https://www.ncbi. nlm.nih.gov/books/NBK1430/pdf/Bookshelf_NBK1430.pdf

[7] Pietrzak M.K., Kasprzak A., Mazur M., et àl.: Zespót Sturge'a-Weberaaktualne rekomendacje diagnostyczno-terapeutyczne. Neurologia Dziecięca 2015; 24: 101-108.

[8] Domańska-Pakieła D., Kotulska K., Jóźwiak S.: Stwardnienie guzowate: postępy w diagnostyce i leczeniu. Neurol Dziec 2008; 17: 11-22.

[9] Stolarska U., Kaciński M.: Diagnoza neuropsychologiczna u dzieci. Prz. Lek. 2007; 64: 978-984.

[10] Crawford J.R., Parker D.M., McKinlay W.W.: A Handbook of Neurological Assessment. Routledge, London 2018.

[11] Bachański M.: Dieta ketogenna w neurologii dziecięcej. Opieka Paliatywna nad Dziećmi 2009; 17: 215-217.

[12] Dudzińska M.: Dieta ketogenna. Kiedy nie pomagają leki przeciwpadaczkowe. Wydawnictwo Lekarskie PZWL, Warszawa 2015.

[13] Papandreou D., Pavlou E., Kalimeri E., et al.: The ketogenic diet in children with epilepsy. British Journal of Nutrition 2006; 95: 5-13.

[14] Wu Q., Wang H., Fan Y.Y., et al: Ketonic diet effects on 52 children with pharmacoresistant epileptic encephalopathy: A clinical prospective study. Brain and Behaviour 2018, 8, Address: https://onlinelibrary.wiley. $\mathrm{com} / \mathrm{doi} / \mathrm{full} / 10.1002 / \mathrm{brb3} .973$

[15] de Kinderen, R., Lambrechts D., Postulart D., et al.: Research into the (Cost-) effectiveness of the ketogenic diet among children and adolescents with intractable epilepsy: design of a randomized controlled trial. BMC Neurology 2011, 11, Address: https://bmcneurol.biomedcentral. com/articles/10.1186/1471-2377-11-10

[16] Lambrechts D.A.J.E., Bovens M.J.M., de la Parra N.M., et al.: Ketogenic diet effects on cognition, mood, and psychosocial adjustment in children. Acta Neurologica Scandinavica 2010; 127: 103-108.

[17] Ramm-Pettersen A., Stabell K.E., Nakken K.O., et al.: Does ketogenic diet improve cognitive function in patients with GLUT1-DS? A 6- to 17-month follow-up study. Epilepsy \& Behaviour 2014; 39: 111-115.

[18] Lezak M.D., Howieson D.B., Loring D.W., et al.: Neuropsychological Assessment. Oxford University Press, 0xford 2004.

[19] Zhu D., Wang M., Wang J., et al.: Ketogenic diet effects on neurobehavioral development of children with intractable epilepsy: A prospective study. Epilepsy \& Behavior 2016; 55: 87-91.
[20] Ni U., Wang X., Zhang L., et al: Prospective study of the efficacy of a ketogenic diet in 20 patients with Dravet syndrome. Seizure 2018; 60: 144-148.

[21] Kurowska K.: Nieprawidłowy rozwój psychomotoryczny dzieci. Część I: podstawowa definicja i informacje. Pediatria i Medycyna Rodzinna 2018; 14: $143-50$.

[22] Cardoso F.G.C., Formiga C.K.M.R., Bizinotto T., et al.: Concurrent Validity of the BrunetLézine Scale with the Bayley Scale for assessment of the development of preterm infants up to two years. Revista Paulista de Pediatria 2017; 35: 144-150.

[23] Kowalczykiewicz-Kuta A.: Kamienie milowe we wczesnej ocenie rozwoju dziecka. [w:] Wybrane aspekty opieki pielęgniarskiej i położniczej w różnych specjalnościach medycyny, t. 6. Siekierka, J., Zimnowoda, M., Żurawicka, D. [red], Państwowa Medyczna Wyższa Szkoła w Opolu, Opole 2018.

[24] Goertzel B., Wang P.: Advances in artificial general intelligence: concepts, architectures and algorithms. IOS Press, Amsterdam 2007.

[25] LaRue A.: Aging and Neuropsychological Assessment. Plenum Press, New York 1992.

[26] Jaworowska A., Matczak A., Szustrowa T.: Międzynarodowa Wykonaniowa Skala Leitera P-93. Podręcznik. Pracownia Testów Psychologicznych PTP, Warszawa 1996.

[27] Ciechanowic A.: Skala Dojrzałości Umysłowej Columbia. Pracownia Testów Psychologicznych PTP, Warszawa 1990.

[28] Szustrowa T., Jaworowska A.: Test Matryc Ravena w Wersji Kolorowej. Formy: Klasyczna i Równoległa. Podręcznik. Pracownia Testów Psychologicznych PTP, Warszawa 2003.

[29] Jaworowska A., Szustrowa T.: Test Matryc Ravena w Wersji Standard. Formy: Klasyczna, Równoległa, Plus. Pracownia Testów Psychologicznych PTP, Warszawa 2000.

[30] Matczak A., Piotrowska A., Ciarkowska W.: Skala Inteligencji D. Wechslera dla Dzieci - Wersja Zmodyfikowana (WISC-R). Podręcznik. Pracownia Testów Psychologicznych PTP, Warszawa 2008.

[31] Brzeziński J., Gaul M., Hornowska E., et al.: Skala Inteligencii D. Wechslera dla Dorosłych. Wersja zrewidowana - renormalizacja WAIS-R(PL). Podręcznik. Pracownia Testów Psychologicznych PTP, Warszawa 2004.

[32] Nęcka E.: Procesy uwagi. [w:] Psychologia. Podręcznik akademicki, t. 2: Psychologia ogólna. Strelau, J. [red.], Gdańskie Wydawnictwo Psychologiczne, Gdańsk 2000.

[33] Dajek E.R.: Test d2. Test badania uwagi. Wydawnictwo ERDA, Warszawa 2003.

[34] Strupczewska B.: Test Figury Złożonej Rey-0sterrietha (TFZ). Podręcznik. Centralny Ośrodek Metodyczny Poradnictwa WychowawczoZawodowego MEN, Warszawa 1990.

[35] Sivan A.B.: Test Pamięci Wzrokowej Bentona. Podręcznik. Pracownia Testów Psychologicznych Polskiego Towarzystwa Psychologicznego, Warszawa 2007.

[36] Borkowska A., Sobów, T.: Ocena neuropsychologiczna w diagnostyce i różnicowaniu otępienie czołowo-skroniowego. Neurologia i Neurochirurgia Polska 2005; 39: 466-475.

[37] Jaworska J.: Test Bender-Koppitz. Podręcznik. Centralny Ośrodek Metodyczny Poradnictwa Wychowawczo-Zawodowego MEN, Warszawa 1990.

[38] Jodzio K.: Neuropsychologia intencjonalnego działania. Koncepcje funkcji wykonawczych. Wydawnictwo Naukowe Scholar, Warszawa 2008.

[39] Rakoczy W.: Neurologiczna ocena funkcji wykonawczych - przegląd. Postępy Psychiatrii i Neurologii 2015; 24: 99-105.

[40] Jaworowska A.: Test Sortowania Kart z Wisconsin. Podręcznik. Pracownia Testów Psychologicznych PTP, Warszawa 2002.

[41] Piskunowicz M., Bieliński M., Zgliński A., et al.: Testy fluencji słownejzastosowanie w diagnostyce neuropsychologicznej. Psychiatra Polska 2013, 47: 475-485. 